JAMP: Jurnal Adminitrasi dan Manajemen Pendidikan

Volume 1 Nomor 4 Desember 2018, Hal : 381-387

Tersedia Online di http://journal2.um.ac.id/index.php/jamp/

ISSN 2615-8574 (online)

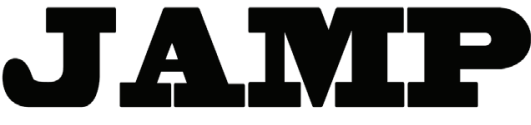

JURNAL ADMINISTRASI DAN MANAJEMEN PENDIDIKAN

\title{
STRATEGI KEPALA SEKOLAH DALAM PENCAPAIAN PRESTASI TERBAIK PADA LOMBA KEPALA SEKOLAH BERPRESTASI
}

\author{
Paxia Izzatul Umam Irhami \\ Ahmad Supriyanto \\ Raden Bambang Sumarsono
}

paxia.izza@gmail.com

Universitas Negeri Malang, Jalan Semarang No.5 Malang

\begin{abstract}
This study aims to determine (1) the background of the principal in the best achievement; (2) habits of principals who can support the best achievement; (3) the efforts made by the principal who can support the best achievement; and (4) the supporting factors of the best achievement on talented principal competition. The research method used qualitative with a multi-case study approach. At the data processing stage, data analysis uses a single case and continued with cross-case analysis. The results of the study show, from the background of achievement is one such as the headmaster who likes to compete and trust from others, habits that support achievement such as sharing knowledge ang following organizations, efforts made in achieving achievement in the form of training and best practice, and the supporting factors of the best achievement such as personal motivation and motivation of others. Overall, the findings each of the research focuses are influenced by intrinsic factors and extrinsic factors of high achieving principals.
\end{abstract}

Keywords : strategy, head master, achievement

\begin{abstract}
Abstrak : Penelitian ini bertujuan untuk mengetahui (1) latar belakang kepala sekolah dalam pencapaian prestasi terbaik; (2) kebiasaan kepala sekolah yang dapat menunjang pencapaian prestasi terbaik; (3) usaha yang dilakukan kepala sekolah dalam pencapaian prestasi terbaik; dan (4) faktor pendukung pencapaian prestasi terbaik pada lomba kepala sekolah berprestasi. Metode penelitian yang digunakan adalah kualitatif dengan pendekatan studi multi kasus. Pada tahap pengolahan data, analisis data menggunakan kasus tunggal dan dilanjutkan dengan analisis lintas kasus. Hasil penelitian menunjukkan, dari latar belakang pencapaian prestasi salah satunya seperti dari pribadi kepala sekolah yang suka berkompetisi dan kepercayaan dari orang lain, kebiasaan yang menunjang prestasi seperti berbagi ilmu dan mengikuti organisasi, usaha yang dilakukan dalam pencapaian prestasi berupa mengikuti pelatihan juga best practice, dan faktor pendukung pencapaian prestasi terbaik seperti motivasi pribadi juga adanya motivasi dari orang lain. Secara keseluruhan, temuan dari masing-masing fokus penelitian tersebut dipengaruhi oleh faktor intrinsik dan faktor ekstrinsik dari kepala sekolah berprestasi.
\end{abstract}

Kata kunci: strategi, kepala sekolah, prestasi

Kebutuhan berprestasi salah satu bentuk dari realisasi Undang-Undang Republik Indonesia Nomor 20 Tahun 2003, tentang Sistem Pendidikan Nasional, Pasal 40 Ayat (2), dinyatakan bahwa pendidik dan tenaga kependidikan berkewajiban memberi teladan dan menjaga nama baik lembaga, profesi, dan kedudukan dengan kepercayaan yang diberikan kepadanya. Akan tetapi tidak banyak kepala sekolah yang bisa mencapai hal tersebut. 
Usaha perolehannya dapat dilakukan salah satunya dengan adanya kebutuhan akan pencapaian prestasi, karena hal itu merupakan sebuah dorongan agar lebih unggul dari orang lain demi mencapai keberhasilan. Seperti yang dijelaskan oleh McClelland dalam Winardi (2001), bahwa kebutuhan berprestasi meliputi beberapa keinginan untuk meraih keberhasilan, mengatasi rintangan menyelesaikan suatu permasalahan yang dianggap termasuk dalam kategori sulit untuk dapat melebihi orang lain.

Penelitian ini membahas kepala sekolah berprestasi, untuk mengupas bagaimana strateginya dalam meraih prestasi terbaik pada kompetisi kepala sekolah berprestasi dengan seleksi berjenjang. Berdasarkan hasil studi pendahuluan mengungkap tentang kebiasaan, usaha, dan faktor pendorong yang bersangkutan ketika mengikuti lomba tersebut. Seperti melalui wawancara dengan Kepala SMAN 6 Malang diperoleh gambaran bahwa latar belakang atau motivasi untuk mengikuti lomba hingga meraih juara ialah karena kepercayaan yang sudah diberikan kepada kepala sekolah untuk mengikuti lomba maka harus melakukan yang terbaik hingga akhir. Secara lengkap hasil studi penelitian melalui wawancara dengan Kepala SMAN 6 Malang adalah sebagai berikut. "Yang menjadi motivasi kepala sekolah untuk meraih prestasi terbaik ini ialah kepercayaan, .... Seandainya terpilih mewakili kota Malang untuk maju ke provinsi, maka kepercayaan pengirim yang menjadi motivasi” (W/HO/002/F1/10.01.2018)

Dari hasil studi pendahuluan yang dilakukan, contohnya juga diketahui mengenai faktor pendukung pencapaian prestasi ini. Salah satu faktornya seperti dukungan yang diberikan secara moral, karena meskipun hanya kepala sekolah yang mengikuti lomba namun tidak akan berjalan dengan baik lomba itu jika tidak ada pihak yang mendukung. Hal ini mengacu pada pendapat dari Kepala SDN Lesanpuro 1 Malang. "Faktor pendukung secara moril dari teman sejawat yang tetap melaksanakan tugas .... Dari pengawas pula yang mendorong kepala sekolah ketika mengikuti lomba" (W/OW/001/ F4/02.04.2018)

Perbedaan penelitian ini bila dibandingkan dengan penelitian terdahulu ialah jika penelitian ini mengungkap strategi yang dilakukan oleh kepala sekolah untuk mencapai prestasi pribadi kepala sekolah itu sendiri, sebaliknya penelitian sebelumnya umumnya mengungkap strategi kepala sekolah berfokus pada peningkatan mutu, prestasi atau fisik sekolah maka cenderung lebih ke organisasinya. Penelitian terdahulu tersebut beberapa diantaranya seperti strategi kepala sekolah dalam peningkatan mutu pendidikan studi kasus di SMAN 1 Purwosari Pasuruan (Azizah, 2016) dan strategi kepala sekolah dalam meningkatkan sarana untuk menunjang inovasi pembelajaran di SMK Ma'aruf NU 04 Pakis (Maghfiroh, 2017).

Tugas kepala sekolah, seperti yang disampaikan oleh Makawimbang (2012:81), bahwa kepala sekolah memiliki tugas yang kompleks sebagai pengembang sekolah. Tugas kepala sekolah dapat digolongkan menjadi tujuh pokok yaitu sebagai pendidik, manajer, administrator, supervisor, leader, inovator, motivator. Juga diharapkan dapat memahami kompetensi sebagai kepala sekolah, menurut Peraturan Menteri Pendidikan Nasional RI Nomor 13 Tahun 2007 kompetensi tersebut diantaranya ialah kompetensi kepribadian, manajerial, kewirausahaan, supervisi, dan sosial. Pelaksanaan dari tugas kepala sekolah dibutuhkan motivasi untuk memenuhinya, salah satunya dengan motivasi berprestasi. Pengertian dari motivasi berprestasi sendiri menurut McClelland (1987:40) ialah usaha mencapai sukses atau berhasil dalam kompetisi dengan ukuran keunggulan yang dapat berupa prestasi orang lain maupun prestasi sendiri. Faktor yang mempengaruhi peraihan prestasi menurut Djali (2008:101), yaitu faktor intrinsik yang berasal dari dalam diri individu dan faktor ekstrinsik yang berasal dari luar diri individu. Untuk komponen motivasi berprestasi dapat diklasifikasikan menjadi empat komponen yaitu (1) risiko pemilihan tugas; (2) umpan balik; (3) tanggung jawab; dan (4) kreatif-inovatif (McClelland dalam Adibah, 2011:6)

Kompetisi yang dilakukan secara selektif tidak semua kepala sekolah dapat meraih prestasi tersebut, dan dengan prestasi yang di raih oleh kepala sekolah juga dapat berimbas pada prestasi lembaganya. Maka ada berbagai upaya yang dilakukan oleh kepala sekolah yang terpilih itu. Upaya apa saja yang dilakukan oleh masing-masing kepala sekolah dengan jenjang yang berbeda inilah yang berusaha diungkap dalam penelitian ini. Berdasarkan pemikiran yang diungkap oleh informan di atas, menjadi urgensi pentingnya untuk diungkap lebih lanjut mengenai strategi kepala sekolah dalam pencapaian prestasi terbaik pada lomba kepala sekolah berpretasi. 


\section{METODE}

Pendekatan yang dilakukan oleh peneliti ialah pendekatan kualitatif. Pemilihan pendekatan kualitatif ini karena peneliti ingin mengkaji lebih dalam mengenai strategi kepala sekolah dalam pencapaian prestasi terbaik. Jenis penelitian yang digunakan yaitu penelitian multi kasus, karena jenis penelitian ini melibatkan dua atau lebih subjek atau tempat penelitian (Ulfatin, 2005:68-69). Dikatakan multi kasus karena dalam penelitian ini melibatkan tujuh kepala sekolah dengan jenjang yang berbeda mulai dari tingkat TK, SD, SMP, SMA, dan SMK di Kota Malang. Lokasi penelitian yaitu TK Nurul Huda, SDN Lesanpuro 1 Malang, SMPN 4 Malang, SMPN 24 Malang, SMAN 3 Malang, SMAN 6 Malang, SMAN 7 Malang, SMAN 10 Malang, SMKN 11 Malang, dan SMKN 13 Malang.

Pengumpulan data menggunakan teknik wawancara, observasi, dan dokumentasi. Wawancara dilakukan pada 7 narasumber kunci, dan 30 narasumber tambahan untuk memperkuat atau memperdalam penggalian informasi. Selanjutnya pengamatan yang dilakukan disini berdasarkan hasil wawacara. Observasi yang dilakukan mengenai best practice kepala sekolah dirinci pada Tabel 1.

\section{Tabel 1.Judul Pengamatan}

\begin{tabular}{|c|c|c|}
\hline No. & Nama & Pengamatan \\
\hline 1 & Muslimah Rinasyaadah & $\begin{array}{l}\text { Pendidikan Karakter Berbasis Agama Islam (TK Nurul } \\
\text { Huda) }\end{array}$ \\
\hline 2 & Olim Walenti & $\begin{array}{l}\text { Pemanfaatan Lingkungan Sekolah sebagai Literasi (SDN } \\
\text { Lesanpuro } 1 \text { Malang) }\end{array}$ \\
\hline 3 & Hari Subagyo & $\begin{array}{l}\text { Peningkatan Mutu dengan Sentuhan Seni Tradisi Terpadu } \\
\text { (SMPN } 24 \text { Malang) }\end{array}$ \\
\hline 4 & Asri Widyapsari & Tutor Sebaya (SMAN 7 Malang) \\
\hline 5 & Hariyanto & Penanganan Jam Kosong (SMAN 6 Malang) \\
\hline 6 & Husnul Chotimah & Supervisi (SMAN 10 Malang) \\
\hline 7 & Dwi Lestari & Kedisiplinan dari Ibu Dwi (SMKN 13 Malang) \\
\hline
\end{tabular}

Berikutnya teknik dokumentasi, yang didokumentasikan oleh peneliti adalah portofolio dan best practice dari kepala sekolah. Selanjutnya dilakukan analisis data yang dilakukan bertahap, pada awal dilakukan analisis kasus tunggal lalu kemudian analisis lintas kasus (Ulfatin, 2015). Analisis kasus tunggal diawali dengan reduksi data dengan meringkas atau memilah data atau informasi mana yang penting dan sesuai dengan fokus penelitian juga mana yang tidak sesuai, display data dengan menyusun sesuai dengan fokus penelitian, dan verifikasi data mengumpulkan setiap temuan. Selanjutnya dilakukan analisis lintas kasus, proses membandingkan dan memadukan temuan antar kasus yang ada berdasarkan fokus penelitian dengan mengembangkan secara deskriptif dari fenomena yang ada pada semua kasus dengan total ada 7 kasus yang dilakukan analisis lintas kasus.

\section{HASIL}

\section{Temuan Peneliti pada Kasus 1 Kepala TK Berprestasi 2016}

Latar belakang pencapaian prestasi dari Ibu Muslimah Rinasyaadah ialah adanya bantuan dan dukungan, kepercayaan, keyakinan bahwa dapat memberi kebaikan bagi lembaganya. Kebiasaan yang dilakukan antara lain yaitu terkait dengan tupoksi kepala sekolah, mengikuti kegiatan organisasi dan menulis. Usaha yang dilakukan dengan cara memperbanyak ilmu, bimbingan dengan guru berprestasi, dan mengikuti pelatihan, best practice pendidikan karakter berbasis agama islam. Program yang inovatif dan pengalaman mengikuti lomba kepala sekolah berprestasi sebelumnya merupakan faktor pendukung pencapaian prestasi terbaik. 


\section{Temuan Peneliti pada Kasus 2 Kepala SD Berprestasi 2016}

Latar belakang dari Ibu Olim Walenti dalam pencapaian prestasi ialah adanya dukungan, pribadi yang suka untuk mencoba, dan menambah pengalaman baru. Kebiasaan yang dapat menunjang pencapaian prestasi ialah semua aktivitas dilakukan secara on time, mengawasi KBM, rutin menyantuni anak yatim. Usaha yang dilakukan yaitu meningkatkan prestasi sekolah, memahami prosedur dan mengimplementasikannya dengan baik, tidak banyak bicara namun banyak bekerja, memberi contoh baik, mendapat bimbingan dari suami dan kepala sekolah berprestasi sebelumnya, mengikuti banyak pelatihan, dan best practice pemanfaatan lingkungan literasi. Adanya dukungan dan bantuan, sikap ketika tes dan presentasi, dan pengalaman bidang pendidikan juga mengikuti lomba kepala sekolah berprestasi sebelumnya yang menjadi faktor pendukung kepala sekolah dalam pencapaian prestasi terbaik, selain itu juga dari

\section{Temuan Peneliti pada Kasus 3 Kepala SMP Berprestasi 2015}

Latar belakang dari pencapaian prestasi Bapak Hari Subagyo ialah dari adanya pihak yang mendukung, adanya keinginan untuk mencoba. Kebiasaan yang menunjang pencapaian prestasi antara lain yaitu yang terkait dengan tupoksi kepala sekolah, berbagi ilmu dengan para guru, kedisiplinan dan dari religi juga taat beribadah. Usaha ketika mencapai prestasi yaitu memahami prosedur ketika mengikuti kompetisi dan menjalankannya dengan cara menekankan poin tertinggi yaitu dari karya ilmiah, mengikuti berbagai pelatihan, dan mendapat bimbingan dari kepala sekolah berprestasi pada tahun sebelumnya, best practice PPST (Pendidikan Pengembangan Seni Tradisi) di SMPN 24 Malang. Faktor pendukung hingga meraih prestasi ialah memegang poin tertinggi yaitu dalam karya ilmiah dengan mengangkat program inovatif PPST.

\section{Temuan Peneliti pada Kasus 4 Kepala SMA Berprestasi 2014}

Adanya pihak yang mendukung serta adanya kepercayaan, dan mengusahakan untuk jadi yang terbaik adalah latar belakang kepala sekolah dari Ibu Asri Widyapsari. Kebiasaan antara lain yaitu terkait dengan tupoksi kepala sekolah, rutin memotret dan mengamati setiap perbaikan sekolah, sharing ilmu bersama teman-teman MGMP, selanjutnya membaca dan menulis, juga membuat catatan atas setiap apa yang akan dilakukan. Usaha yang dilakukan diantaranya yaitu merealisasi ide-ide kreatif milik beliau, best practice tutor sebaya di SMAN 7 Malang, mematangkan perencanaan, melakukan perubahan pada lembaga, senantiasa memotivasi guru dan memberi sarana atas pengembangan karirnya, manajemen waktu dan mengikuti banyak pelatihan. Faktor pendukung hingga meraih prestasi terbaik sebagai berikut, harus memiliki visi yang jelas dalam hidup, adanya target mutu dan waktu, yakin kepada Tuhan Yang Maha Esa, mengusahakan yang terbaik dan apa adanya.

\section{Temuan Peneliti pada Kasus 5 Kepala SMA Berprestasi 2016}

Latar belakang kepala sekolah dalam pencapaian prestasi terbaik dari Bapak Hariyanto adalah kepercayaan, dukungan dan bantuan, adanya keyakinan, dan motivasi pribadi untuk menjadi yang terbaik. Kegiatan rutin antara lain yaitu kegiatan yang sesuai dengan tupoksi dan kompetensi kepala sekolah, juga menulis. Usaha yang dilakukan ialah penerapan 3P (peningkatan penampilan, pelayanan, dan prestasi) dalam lembaganya, mengikuti proses sesuai dengan prosedur, mengikuti pelatihan, best practice penanganan jam kosong, dan persiapan dengan baik. Faktor pendukung pencapaian prestasi yaitu banyak pengalaman dalam bidang pendidikan, mengikuti proses dengan baik, dan dengan menampilkan hal-hal yang realita.

\section{Temuan Peneliti pada Kasus 6 Kepala SMK Berprestasi 2014}

Latar belakang dalam pencapaian prestasi dari Ibu Dwi Lestari ialah adanya dukungan dan bantuan, kepercayaan, melakukan dengan maksimal, menargetkan untuk hasil yang terbaik, memahami dengan benar kompetensi kepala sekolah. Kebiasaan yang menunjang pencapaian prestasi yaitu membuat draft atau catatan kecil mengenai apa yang ingin dilakukan, menulis, rutin untuk mengawasi KBM. Usaha yang dilakukan antara lain yaitu menjadi dasar pengembangan bagi lembaganya, manajemen waktu, mengikuti pelatihan, best practice penitipan bayi di SMKN 11 Malang. Faktor pendukung yaitu dari 
adanya motivasi pribadi untuk menjadi yang terbaik, motivasi serta kepercayaan dari orang lain, terakhir dengan doa kepada Tuhan.

\section{Temuan Peneliti pada Kasus 7 Kepala SMK Berprestasi 2016}

Adanya pihak yang membantu dan mendukung, serta kepercayaan merupakan latar belakang pencapaian prestasi terbaik oleh Ibu Husnul Chotimah. Kebiasaan dari beliau antara lain ialah kegiatan yang terkait dengan tupoksi kepala sekolah, membaca, pemberian contoh baik, rutin mengawasi KBM, dan taat beribadah. Usaha yang ialah dengan melakukan pengembangan sekolah, memahami dan mengikuti prosedur dengan baik, memperbanyak pengalaman, best practice supervisi lesson study di SMKN 13 Malang. Faktor pendukungnya adalah sejalannya manajemen dan sistem, banyaknya karya yang dihasilkan dan diterbitkan, pribadi yang berusaha untuk beda dari kepala sekolah lain, dengan kata lain beliau termasuk kepala sekolah yang inovatif.

\section{Temuan Peneliti pada Kasus 6 Kepala SMK Berprestasi 2014}

Latar belakang dalam pencapaian prestasi dari Ibu Dwi Lestari ialah adanya dukungan dan bantuan, kepercayaan, melakukan dengan maksimal, menargetkan untuk hasil yang terbaik, memahami dengan benar kompetensi kepala sekolah. Kebiasaan yang menunjang pencapaian prestasi yaitu membuat draft atau catatan kecil mengenai apa yang ingin dilakukan, menulis, rutin untuk mengawasi KBM. Usaha yang dilakukan antara lain yaitu menjadi dasar pengembangan bagi lembaganya, manajemen waktu, mengikuti pelatihan, best practice penitipan bayi di SMKN 11 Malang. Faktor pendukung yaitu dari adanya motivasi pribadi untuk menjadi yang terbaik, motivasi serta kepercayaan dari orang lain, terakhir dengan doa kepada Tuhan.

\section{Temuan Peneliti pada Kasus 7 Kepala SMK Berprestasi 2016}

Adanya pihak yang membantu dan mendukung, serta kepercayaan merupakan latar belakang pencapaian prestasi terbaik oleh Ibu Husnul Chotimah. Kebiasaan dari beliau antara lain ialah kegiatan yang terkait dengan tupoksi kepala sekolah, membaca, pemberian contoh baik, rutin mengawasi KBM, dan taat beribadah. Usaha yang ialah dengan melakukan pengembangan sekolah, memahami dan mengikuti prosedur dengan baik, memperbanyak pengalaman, best practice supervisi lesson study di SMKN 13 Malang. Faktor pendukungnya adalah sejalannya manajemen dan sistem, banyaknya karya yang dihasilkan dan diterbitkan, pribadi yang berusaha untuk beda dari kepala sekolah lain, dengan kata lain beliau termasuk kepala sekolah yang inovatif.

\section{PEMBAHASAN}

\section{Latar belakang kepala sekolah dalam pencapaian prestasi terbaik pada lomba kepala sekolah berprestasi}

Adanya kepercayaan orang lain bahwa kepala sekolah tersebut mampu meraih juara, dan adanya pihak yang mendukung dan membantu serta mempercayakan kepala sekolah sekolah ini termasuk dalam faktor dorongan berprestasi dari luar sesuai dengan penjelasan dari Djaali (2008:101), bahwa faktor ekstrinsik merupakan faktor yang berasal dari luar diri individu atau lingkungan. Faktor ini terdiri dari faktor situasional, norma kelompok, resiko yang ditimbulkan sebagai akibat dari prestasi yang diperoleh, sikap terhadap kehidupan dan lingkungan, serta pengalaman yang dimiliki. Dengan adanya kepercayaan, bantuan, serta dukungan dari warga sekolah, menjadikan kepala sekolah tidak dapat melakukan tugas dan tanggung jawabnya. Jadi terdapat keterkaitan antara kepala sekolah dan warga sekolahnya. Sesuai dalam jurnal JMSP milik Saputra (2018), Membangun hubungan yang baik dengan semua warga sekolah dan masyarakat di SDIT Ahmad Yani Kota Malang kepala sekolah melibatkan peran serta guru, tenaga kependidikan, wali murid, dan masyarakat sebagai stakeholder. 


\section{Kebiasaan kepala sekolah yang dapat menunjang pencapaian prestasi terbaik pada lomba kepala sekolah berprestasi}

Kebiasaan dari kepala sekolah yang menunjang pencapaian prestasi terbaik ialah dari rutinitas yang sesuai dengan tupoksi sebagai kepala sekolah. Seperti yang disampaikan oleh Wiyono, (2013:39) tugas seorang kepala sekolah adalah merencanakan, mengorganisir, mengkoordinir, melakukan komunikasi, mempengaruhi, dan mengadakan evaluasi merupakan komponen-komponen tugas proses. Membaca dan menulis, dengan membaca dapat memperkaya ilmu yang juga termasuk dalam pengembangan diri. Sesuai dengan kompetensi kepribadian kepala sekolah yaitu memiliki keinginan yang kuat dalam pengembangan diri sebagai kepala sekolah (Sagala dalam Makawimbang, 2012:65). Lalu dari menulis dapat bahan sharing ilmu dengan orang lain. Didukung oleh pendapat dari Makawimbang (2012:81), bahwa kepala sekolah sebagai pendidik atau edukator memiliki tujuh tugas penting yaitu mengajar di kelas, membimbing guru, membimbing karyawan, membimbing siswa, mengembangkan staf, mengikuti perkembangan IPTEK, dan memberikan contoh bimbingan konseling atau karir yang baik.

\section{Usaha-usaha yang dilakukan kepala sekolah dalam pencapaian prestasi terbaik pada lomba kepala sekolah berprestasi}

Usaha yang dilakukan kepala sekolah dalam pencapaian prestasi terbaik pada lomba kepala sekolah berprestasi disini yaitu melakukan pengembangan sekolah salah satunya melalui best practice kepala sekolah. Sama halya dengan pendapat milik Ariyanti (2018), penyusunan program memerlukan pertimbangan warga sekolah. Yang didukung juga dari pendapat Rahayu dalam Ariyanti (2018), keberhasilan sekolah dalam melaksanakan program pendidikan dan pengembangan perlu didukung dengan efektifitas kepemimpinan pendidikan yang dijalankan oleh eksekutif lembaga pendidikan khususnya para kepala sekolah, pengawas, maupun administrator lain yang diberi tugas dan tanggung jawab untuk mengambil inisiatif pelaksanaan fungsi kepemimpinan pendidikan di sekolah.

Selanjutnya mempersiapkan dasar dari kompetisi dengan matang, mengikuti pelatihan sebagai pendidik, juga mendapat bimbingan dari guru atau kepala sekolah berprestasi sebelumnya. Tiga hal ini dilakukan atas dasar pengembangan diri. Pengembangan diri ini termasuk dalam kompetensi kepribadian, dari pengertiannya sudah dapat terlihat keterkaitan antara pengembangan diri kepala sekolah dengan kompetensi kepribadian. Pengertiannya yaitu kompetensi kepala sekolah yang berkaitan dengan sikap, karakter, dan perilaku pribadi kepala sekolah sesuai nilai dan norma yang baik. Kompetensi tersebut mencakup dimensi kompetensi memiliki keinginan yang kuat dalam pengembangan diri sebagai kepala sekolah atau madrasah (Wiyono, 2013:46). Hal yang serupa juga disampaikan oleh Marhawati (2017), kepemimpinan kepala sekolah adalah salah satu faktor yang dapat mendorong sekolah untuk dapat mewujudkan visi, misi, tujuan, dan sasaran sekolahnya melalui program-program yang dilaksanakan secara terencana dan bertahap. Oleh karena itu, kepala sekolah dituntut mempunyai kemampuan manajemen dan kepemimpinan yang memadai agar mampu meningkatkan mutu sekolah.

\section{Faktor pendukung kepala sekolah dalam pencapaian prestasi terbaik pada lomba kepala sekolah berprestasi}

Pencapaian prestasi kepala sekolah tidak terlepas dari faktor pendukung yang menjadi alasan hingga kepala sekolah tersebut mencapai prestasi terbaiknya. Berikut merupakan faktor pendukung kepala sekolah dalam pencapaian prestasi terbaik pada lomba kepala sekolah berprestasi yaitu pertama, adanya motivasi dari pribadi dan dari luar, juga kepercayaan dari orang lain terhadap pribadi kepala sekolah yang menjadikan kepala sekolah lebih mengusahakan hingga meraih prestasi. Ada kesesuaian dengan pendapat dari Crow (1977:350), dijelaskan bahwa motivasi berprestasi dapat dipengaruhi oleh lingkungan. Lingkungan dapat berupa lingkungan fisik yaitu sekolah dan sarana prasarana maupun nonfisik yaitu kepala sekolah, guru, peserta didik dan wali murid. Kepala sekolah yang inovatif maka akan menghasilkan program yang inovatif pula, selaras dengan dimensi kompetensi kewirausahaan kepala sekolah menurut Wahyudi (dalam Makawimbang, 2012:66) yaitu menciptakan inovasi yang berguna bagi pengembangan sekolah. 
Melakukan usaha terbaik dan apa adanya. Sama halnya dengan salah satu karakteristik individu yang memiliki motivasi berprestasi yang tinggi, yaitu perasaan yang kuat untuk mencapai tujuan dan keinginan untuk menyelesaikan tugas dengan hasil yang sebaik-baiknya (McClelland, 1987:77). Pengalaman mengikuti kepala sekolah berprestasi sebelumnya dan pengalaman di bidang pendidikan lain. Pengalaman yang dimiliki ini termasuk dalam motivasi berprestasi faktor ekstrinsik menurut Djaali (2008:101), faktor ini terdiri dari faktor situasional, norma kelompok, resiko yang ditimbulkan sebagai akibat dari prestasi yang diperoleh, sikap terhadap kehidupan dan lingkungan, serta pengalaman yang dimiliki.

\section{KESIMPULAN}

Kesimpulan penelitian adalah sebagai berikut: (1) latar belakang kepala sekolah dalam pencapaian prestasi terbaik pada lomba kepala sekolah berprestasi antara lain yaitu keyakinan, adanya pihak yang mendukung dan membantu, adanya kepercayaan orang lain , suka berkompetisi dan keinginan untuk mencoba, menguasai kompetensi kepala sekolah, mengusahakan jadi yang terbaik dan menargetkan juara; (2) dari kebiasaan kepala sekolah antara lain yaitu rutinitas yang sesuai dengan tupoksi kepala sekolah, membaca dan menulis, berbagi ilmu, mencatat apa yang akan dilakukan, dari segi religi baik, mengamati kegiatan KBM dan mengamati juga memotret perkembangan lembaganya, juga mengikuti organisasi; (3) usaha yang dilakukan yaitu melakukan pengembangan sekolah, best practice kepala sekolah, mempersiapkan dasar dari kompetisi dengan matang, mengikuti pelatihan, bimbingan dari guru atau kepala sekolah berprestasi sebelumnya, pemanfaatan waktu, memberi contoh baik, mendukung pengembangan karir guru, dan merealisasikan ide kreatif; dan (4) faktor pendukung atas pencapaian prestasi yaitu adanya motivasi dari pribadi dan dari luar, kepala sekolah dan program yang inovatif, memegang poin tertinggi ketika lomba, pengalaman, banyaknya karya, doa, memiliki target waktu dan target mutu dan pekerjaan terencana, juga visi yang jelas, evaluasi, sejalannya manajemen dan sistem, dan sikap ketika tes dan presentasi oleh kepala sekolah.

\section{DAFTAR RUJUKAN}

Adibah, P. 2011. Hubungan antara Motivasi Berprestasi dengan Fear of success pada Wanita Bekerja Dewasa Muda. Jurnal tidak diterbitkan. Jakarta: Fakultas Psikologi Universitas Gunadarma

Ariyanti, N. S. 2018. Kepemimpinan Kepala Sekolah dalam Meningkatkan Partisipasi Masyarakat. JAMP: Jurnal Administrasi dan Manajemen Pendidikan, Vol 1, No 1, 2018. Dari http://journal2.um.ac.id/ index.php/jmap.

Azizah, A. 2016. Strategi Kepala Sekolah dalam Meningkatkan Mutu Pendidikan (Studi Kasus di SMAN 1 Purwosari Pasuruan). Skripsi tidak diterbitkan. Malang: FIP UM.

Djaali. 2008. Psikologi Pendidikan. Jakarta: Bumi Aksara.

Maghfiroh, A. 2017. Strategi Kepala Sekolah dalam Meningkatkan Sarana untuk Menunjang Inovasi Pembelajaran di SMK Ma'arif NU 04 Pakis. Skripsi tidak diterbitkan. Malang: FIP UM.

Makawimbang, J. H. 2012. Kepemimpinan Pendidikan yang Bermutu. Bandung: Alfabeta.

Marhawati, B. 2017. Kepemimpinan Kepala Sekolah Perempuan pada Sekolah Efektif. JMSP: Jurnal Manajemen dan Supervisi Pendidikan, Vol 1, No. 2. Dari http://journal2.um.ac.id/ index.php/jmsp.

McClelland, D. C. 1987. Human Motivation. New York: Cambridge University Press.

Peraturan Menteri Pendidikan Nasional Republik Indonesia Nomor 13 Tahun 2007 tetang Standar Kepala Sekolah/ Madrasah. 2006. Bandung: Citra Umbara

Saputra, B. R. 2018. Keterampilan Manajerial Kepala Sekolah pada Sekolah Berciri Khas Islam. JMSP: Jurnal Manajemen dan Supervisi Pendidikan, Vol 2, No 2. Dari http://journal2.um.ac.id/ index.php/jmsp.

Ulfatin, N. 2015. Metode Penelitian Kualitatif di Bidang Pendidikan: Teori Dan Aplikasinya. Malang: Media Nusa Creative.

Winardi, J. 2001. Motivasi dan Pemotivasian dalam Manajemen. Jakarta: Raja Grafindo Persada.

Wiyono, B. B. 2013. Kepemimpinan Transformasional Kepala Sekolah (Konsep, Pengukuran, dan Pengembangannya). Malang: Fakultas Ilmu Pendidikan Universitas Negeri Malang. 